\section{Ivasenko V., Schweiko V., Kulik $\mathbf{N}$., Havryliuk V.}

\title{
MEASUREMENTS OF ASH EMISSIONS FROM A PLANT FOR BURNING OF RADIOACTIVELY CONTAMINATED WOOD
}

Досліджено ефективність пилогазоочисного устаткування, що встановлено в м. Чорнобиль (Україна) на інсинераторі радіоактивно-забрудненої деревини КВм(а)-2,0. Дана установка включає в себе грубу і тонку очистку (група циклонів типу ЦП-15 та група рукавних фільтрів). У результаті проведених експериментальних досліджень підтверджена ефективність роботи пилогазоочисного устаткування та досягнуто виконання вимог до викидів інсинераторної установки за концентрацією золи до $4 \mathrm{mr} / \mathrm{m}^{3}$.

Ключові слова: викиди забруднюючих речовин, екологічні вимірювання, інсинератор радіоактивно-забрудненої деревини, пилогазоочисне устаткування.

\section{Introduction}

To date, a major problem in the field of pollution, especially the air basin is the burning of forests. There is a pollution of the environment by toxic combustion products (emissions of harmful chemicals into the surface layer of the atmosphere, smoke). Erosion of soils, reduction of river flow, desertification of land - all this is a consequence of a forest fire. There is a violation of the natural carbon cycle, an increase in the concentration of carbon dioxide and, as a consequence, a contribution to global warming.

An actual problem is the forests of the Chernobyl zone, contaminated with radiation, because during a forest fire contamination of radioactive products from the burning of radioactive contaminated wood gets into the air. And further with the wind there is a secondary transfer to other territories and their pollution. However, to date, there are methods to influence this situation. In particular, an incinerator intended for burning of wood, including radioactive contaminated in the Chernobyl Exclusion Zone and the collection of radioactive contaminated ash from dust and gas treatment equipment (DGTE).

\section{The object of research and its technological audit}

The object of research is the efficiency of dust and gas treatment equipment for the removal of contaminated combustion products from the flue gases of the incinerator plant.

Reducing the volume of dry forest in the Chernobyl exclusion zone is aimed at reducing the risk of fires in the region and preventing radioactive contamination by the products of combustion of radioactively contaminated wood. For this purpose, according to the contract with the European Commission within the framework of the project «Technical re-equipment of an industrial building for the plant of an experimental plant for burning of wood Chernobyl, Kirov str., 42» an incinerator was installed on the territory of the Chernobyl zone. The incinerator is a hot water boiler of the $\mathrm{KBM}(\mathrm{a})-2,0$ model with mechanized fuel combustion.
Within the framework of the project, existing modern technologies of burning of wood, technologies for handling contaminated ash and removal of contaminated combustion products from flue gases have been tested and implemented.

One of the most problematic areas of the research facility is that when removing contaminated combustion products (ash) from flue gases, the efficiency of the dust and gas treatment equipment should ensure ash concentrations of up to $4 \mathrm{mg} / \mathrm{m}^{3}$ in the incinerator plant emissions.

\section{The aim and objectives of research}

The aim of this work is an experimental study of the amount of ash emissions that occurs when the dry forest of the Chernobyl Exclusion Zone is controlled.

To achieve this aim, it is necessary to solve the following tasks:

1. To conduct measurements of the ash concentration in the emissions of the incinerator plant.

2. To compare the obtained concentration value with the requirements of the European Union in the flue gas of this incinerator.

\section{Research of existing solutions of the problem}

The assessment of the consequences of radioactive emissions for forestry, and the discussion of the treatment and utilization of radioactive wastes are considered in [1-3]. The plants are designed for incineration of waste - incinerators were widely distributed in the world back in the fifties and sixties [4]. And the use of commercial incineration plants to reduce the volume of radioactive contaminated combustible wastes was first proposed in 1964 [5, 6]. The authors [7, 8] show the technologies for eliminating hazardous wastes and contaminated forests, in which the emissions from combustion plants should contain a minimum amount of contaminated ash. It is described in $[9,10]$ that flue gases are subjected to treatment to reduce emissions of pollutants. At the same time, there is a problem in developing methods and means for flue gas cleaning, which will ensure the lowest values of ash emissions in flue gases. 
On the basis of the analysis, it is practically necessary to determine the efficiency of flue gas cleaning using incinerators of the КВм(a)-2,0 type. This can additionally provide the site with the help of experimental material for further theoretical generalizations.

\section{Methods of research}

Studies were conducted in Chornobyl, Ukraine on an incinerator plant equipped with a gas stream cleaning system and includes coarse and fine cleaning (Fig. 1). Application of two-stage cleaning allows to increase the efficiency of dust and gas cleaning equipment and to reduce emissions of radiation ash. A schematic diagram of the plant is shown in Fig. 2.

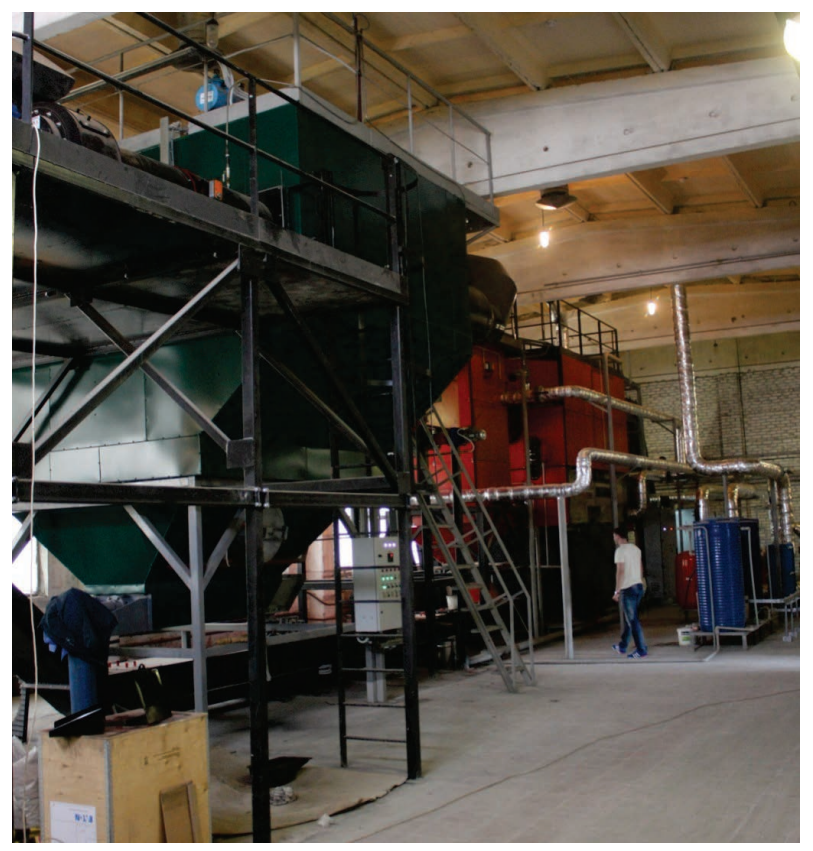

Fig. 1. An incinerator plant for burning of radioactive contaminated wood for the removal of contaminated combustion products from flue gases

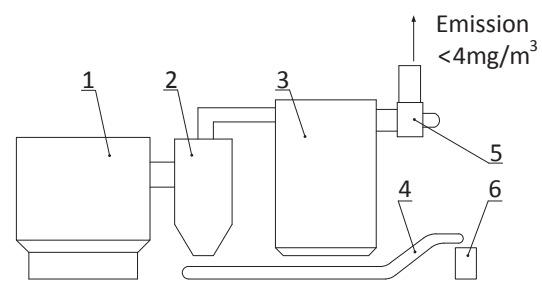

Fig. 2. Schematic diagram of the incinerator plant:

1 - wood incinerator КВм(a)-2,0 type; 2 - group of cyclones of ЦП-15 type; 3 - group of bag filters; 4 - scraper conveyor; 5 - smoke exhauster; 6 - 200 liter storage container

The first stage of treatment is a group of cyclones such as ЦП-15, which are installed behind the boiler and are designed for rough cleaning of dry gases from dust particles larger than 10 microns with an efficiency of $85-98 \%$. The second stage of treatment is a group of bag filters installed between a group of cyclones and a smoke exhaust. The bag filter is dry type dust collection equipment that is used to clean the gas-air mixture and has a high degree of efficiency of 95-99.5\%. All of the trapped ash is removed using a scraper conveyor in a 200 liter storage container.

This design of gas treatment equipment is defined by the requirements of the European Union to the ash content in the flue gases emitted from the plant. According to these requirements, the filtration of flue gases should ensure emissions of ash concentrations to $4 \mathrm{mg} / \mathrm{m}^{3}$, which is much more stringent than the requirements of Ukrainian legislation. In accordance with Order No. 309 of the Ministry of Ecology of June 27, 2006 «On approval of standards for maximum permissible emissions of pollutants from stationary sources», the mass concentration of suspended solids undifferentiated in composition should not exceed $150 \mathrm{mg} / \mathrm{m}^{3}$ with a mass flow rate less than or equal to $0.5 \mathrm{~kg} / \mathrm{h}$.

In order to confirm compliance with the established requirements of the European Union for flue gases, waste, experimental measurements were made during the operation of the incinerator plant.

The measurements were carried out in accordance with MVM No. 081/12-0161-05. This ensures the measurement of the mass concentration of dust in the organized emissions of industrial stationary sources in the range from 1 to $10.000 \mathrm{mg} / \mathrm{m}^{3}$, including the boundaries of the total relative error $\delta \pm 15 \%$, which meets the requirements of RD 52.04.59.

This method of measuring the mass concentration is based on the gravimetric measurement of the dust mass. Dust is accumulated by the filter material during sampling under the condition that the velocities of the gas-dust flow at the sampling point and in the sampling aperture of the variable tip are met (isokinetic condition). The isokineticity condition is realized using a probe with an appropriate diameter of the variable tip and sampling with the calculated gas volume flow rate.

\section{Research results}

In the beginning, measurements are made of the parameters of the gas-dust flow: velocities (GOST 17.2.4.06-90), humidity (GOST 17.2.4.08-90), static pressure and gas-dust flow temperature (GOST 17.2.4.07-90). In the course of the experimental studies, the temperature of the gas-dust mixture did not exceed $100{ }^{\circ} \mathrm{C}$, since the filtering material was used as the filtering element - the cloth lavsan filtering art 860316, TU 17 of the RSFSR 8653-75.

Having measured the flow velocity at the sampling points, and having selected the appropriate tip, the collected probe was introduced into the flue. The volumetric flow rate of the gas-dust flow was established on the rotameter of the aspirating device and the temperature and rarefactions of the gas-dust flow in front of the rotameter were measured. At the same time, the barometric aneroid measured atmospheric pressure.

The parameters of the gas-dust flow are established: temperature $-85^{\circ} \mathrm{C}$, velocity $-7.24 \mathrm{~m} / \mathrm{s}$, volume flow $1.55 \mathrm{~nm}^{3} / \mathrm{s}$. Ambient temperature $-25{ }^{\circ} \mathrm{C}$, atmospheric pressure - $755 \mathrm{kPa}$.

The sampling time of one sample was 20 minutes. At the end of the sampling time, the probe was received from the flue. The filter was after changed for subsequent selection. Five samples were taken.

The filters used were folded in half with a dusty side inward, they were packed in a package with tracing paper, which, in turn, was put into a plastic bag. After it was 
dried, the weights of the filter elements with the sampled dust samples and the control filters were measured. The obtained results allowed to determine the concentration and mass flow of dust at the outlet from the chimney.

Calculation of the dust content of the gas-dust flow $\left(\rho_{b}, \mathrm{mg} / \mathrm{m}^{3}\right)$, measured in the flue-gas section, was made by the formula:

$$
\rho_{b}=\frac{\left(m_{2}-m_{1} \pm m_{x}\right) \cdot 1000}{V_{o}} \cdot 1000,
$$

where $m_{2}$ - the mass of the filter element after sampling, g; $m_{1}$ - the mass of the filter element for sampling, $g ; m_{x}-$ the mass of the blank sample, g; $V_{o}$ - the volume of the sampled gas sample, raised to normal conditions, $\mathrm{dm}^{3}$.

The results of the measurement are summarized in Table 1.

Based on the results of measurements of the dust and gas treatment equipment (Table 1), it is found that the maximum ash concentration is $3.76 \mathrm{mg} / \mathrm{nm}^{3}$ at a mass flow of $0.020981 \mathrm{~kg} / \mathrm{h}$, which meets the requirements.

of low- and intermediate-level nuclear waste «Vector» at the landfill, which corresponds to the Resolution of the Cabinet of Ministers of Ukraine No. 480 from April 29, 1996 «Some Issues of Radioactive Waste Management».

\section{Conclusions}

1. The carried out experimental measurements makes it possible to confirm the efficiency of the dust-and-gas treatment equipment for the removal of contaminated combustion products from the flue gases and allows to meet the ash concentration requirements up to $4 \mathrm{mg} / \mathrm{m}^{3}$, in the incinerator plant.

2. The modern plant for burning of radioactively contaminated wood is equipped with a system of dustfree (dry) ash removal from the boiler and a system for dust-free conditioning of radioactive contaminated ash, fully complies with the requirements of the current Ukrainian and European legislation. That is, the requirements for emissions of the incinerator plant for ash concentration up to $4 \mathrm{mg} / \mathrm{m}^{3}$ have been achieved.

This plant plays an important

Tahle 1 role in reducing emissions and reducing the ecological load of the region and improving the environmental safety of Ukraine.

\begin{tabular}{|c|c|c|c|c|c|c|c|c|}
\hline \multirow{2}{*}{$\begin{array}{c}\text { Name of } \\
\text { source of } \\
\text { pollutant } \\
\text { forma- } \\
\text { tion }\end{array}$} & \multirow{2}{*}{$\begin{array}{l}\text { Sample site } \\
\text { and flue } \\
\text { duct cross- } \\
\text { sectional } \\
\text { area, m }\end{array}$} & \multicolumn{3}{|c|}{$\begin{array}{l}\text { Gas-dust flow parameters } \\
\text { (At the sampling site) }\end{array}$} & \multirow{2}{*}{$\begin{array}{l}\text { Name of pol- } \\
\text { lutant }\end{array}$} & \multirow{2}{*}{$\begin{array}{c}\text { No. of } \\
\text { sam- } \\
\text { ple }\end{array}$} & \multirow{2}{*}{$\begin{array}{c}\text { Mass } \\
\text { concentra- } \\
\text { tion of } \\
\text { pollutant, } \\
\mathrm{mg} / \mathrm{nm}^{3}\end{array}$} & \multirow{2}{*}{$\begin{array}{c}\text { Mass dis- } \\
\text { charge of } \\
\text { pollutant } \\
\text { emission, } \\
q m, g / s\end{array}$} \\
\hline & & $\begin{array}{c}\text { Tem- } \\
\text { perature } \\
t_{g \prime}{ }^{\circ} \mathrm{C}\end{array}$ & $\begin{array}{l}\text { Velocity, } \\
V, \mathrm{~m} / \mathrm{s}\end{array}$ & $\begin{array}{c}\text { volume } \\
\text { flow, } q_{v 0} \\
\mathrm{~nm}^{3} / \mathrm{s}\end{array}$ & & & & \\
\hline \multirow{5}{*}{$\begin{array}{l}\text { Incin- } \\
\text { erator for } \\
\text { burning } \\
\text { of wood }\end{array}$} & \multirow{5}{*}{$\begin{array}{c}\text { After GTU, } \\
D=0.6 \mathrm{~m}\end{array}$} & \multirow{5}{*}{85} & \multirow{5}{*}{7.24} & \multirow{5}{*}{1.55} & \multirow{5}{*}{$\begin{array}{l}\text { Substances } \\
\text { in the form } \\
\text { of suspended } \\
\text { solids undif- } \\
\text { ferentiated in } \\
\text { composition }\end{array}$} & 1 & 3.76 & 0.005828 \\
\hline & & & & & & 2 & 3.12 & 0.004836 \\
\hline & & & & & & 3 & 3.56 & 0.005518 \\
\hline & & & & & & 4 & 3.45 & 0.005348 \\
\hline & & & & & & 5 & 3.34 & 0.005177 \\
\hline
\end{tabular}

\section{References}

1. Belarus - Forestry Sector Development Project: environmental assessment of radiological consequences for forestry in contaminated areas of the Republic of Belarus (Vol. 5) [Electronic resource]: Final report: fire management mission // World Development Sources WDS 1997-2. - Belarus: Government of Belarus. - Available at: \www/URL http://documents.worldbank.org/curated/en/571081468206692053/Final-report-fire-management-mission

\section{SWOT analysis of research results}

Strengths. The tested technology will reduce the emissions of radioactive contaminated ash into the atmosphere. This is due to the use of a two-stage treatment, namely a group of cyclones ЦП-15 and a group of bag filters. At the same time, the expected treatment effect ensures that the ash concentration in the emissions of the domestic pipe is less than $4 \mathrm{mg} / \mathrm{nm}^{3}$.

Weaknesses. Bag filter of dust collecting equipment over time require replacement, which leads to an increase in operating costs. The periodicity of replacement of bag filters at the maximum loading of the plant is 1 year. Estimated cost of filters is $\$ 1500$. The constant and periodic need to replace filters and financial costs can be a serious obstacle in meeting the ash content requirements in flue gases ejected from the plant.

Opportunities. A significant opportunity is using the heat energy of the incinerator plant for heating water and heating the living quarters, since the unit is built on the basis of the KВм(a)-2,0 boiler. According to the manufacturer's data, the thermal capacity of the boiler is $2000 \mathrm{~kW}$, and the area of the room that can heat is $20.000 \mathrm{~m}^{3}$.

Threats. The trapped radioactive contaminated ash requires further handling of waste, namely the storage
2. Szekely, J. G. Environmental assessment of radiological consequences for forestry in contaminated areas of the republic of Belarus [Text]: Consultant report to the World Bank J. G. Szekely, B. D. Amiro, L. R. Rasmussen, B. Ford. - Washington, USA, January 1994. - 57 p.

3. Dusha-Gudym, S. I. Forest Fires on radionuclide contaminated territories. Guarding and protection of forest, mechanization, using of forest [Text] / S. I. Dusha-Gudym // Revue Information. - 1993. - No. 9. - P. 1-50.

4. Halverson, M. Combustion aerosols formed during burning of radioactively contaminated materials: Experimental results [Text] / M. Halverson, M. Ballinger, G. Dennis. - Office of Scientific and Technical Information (OSTI), 1987. - 59 p. doi:10.2172/6900062

5. McCabe, L. C. Wood-Burning Incinerators ATMOSPHERIC POLLUTION [Text] / L. C. McCabe // Industrial \& Engineering Chemistry. - 1952. - Vol. 44, No. 4. - P. 111A-114A. doi:10.1021/ie50508a008

6. Glauberman, H. The Use of Commercial Incinerators for the Volume Reduction of Radioactively Contaminated Combustible Wastes [Text] / H. Glauberman, P. Loysen // Health Physics. 1964. - Vol. 10, No. 4. - P. 237-241. doi:10.1097/00004032196404000-00003

7. Silcox, G. D. Hazardous Waste Incinerators [Text] / G. D. Silcox, J. S. Lighty, M. E. Keener // Kirk-Othmer Encyclopedia of Chemical Technology. - John Wiley \& Sons, Inc., 2004. doi:10.1002/0471238961.0914030904090513.a01.pub2

8. Greben'kov, A. J. Possible technologies for Belarus forest site remediation after Chernobyl accident [Text] / A. J. Greben'kov, A. Jouve, I. V. Rolevich, I. A. Savushkin // Proceedings of Spectrum 94 Nuclear and Hazardous Waste Management Inter- 
national Topical Meeting. - Atlanta, USA: American Nuclear Society, 1994. - Vol. 3. - P. 1640-1644.

9. Flue gas cleaning for incinerators [Text] // Filtration \& Separation. - 1996. - Vol. 33, No. 3. - P. 178. doi:10.1016/s00151882(96)90781-8

10. Operating experience with filter bags in flue gas cleaning on refuse incinerators // Filtration \& Separation. - 1995. - Vol. 32, No. 1. - P. 27-30. doi:10.1016/s0015-1882(97)84007-4

\section{ИЗМЕРЕНИЯ ВЫБРОСОВ ЗОЛЫ УСТАНОВКИ ПО СЖИГАНИЮ РАДИОАКТИВНО ЗАГРЯЗНЕННОЙ ДРЕВЕСИНЫ}

Исследована эффективность пылегазоочистного оборудования, установленного в г. Чернобыль (Украина) на инсинераторы радиоактивно загрязненной древесины КВм(а)-2,0. Данная установка включает в себя грубую и тонкую очистку (группа циклонов типа ЦП-15 и группа рукавных фильтров). В результате проведенных экспериментальных исследований подтверждена эффективность работы пылегазоочистного оборудования и достигнуты требования по выбросам инсинераторной установки за концентрацией золы до $4 \mathrm{mг} / \mathrm{m}^{3}$.

ключевыг слова: выбросы загрязняющих веществ, экологические измерения, инсинератор радиоактивно загрязненной древесины, пылегазоочистное оборудование.
Ivasenko Vitaliy, PhD, Assistant, Department of Scientific Analytical and Environmental Devices and Systems, National Technical University of Ukraine «Igor Sikorsky Kyiv Polytechnic Institute», Ukraine, e-mail: ivasenko-vitaliy@ukr.net, ORCID: http://orcid.org/ 0000-0001-8318-7437

Shvayko Volodymyr, Department of Scientific Analytical and Environmental Devices and Systems, National Technical University of Ukraine «Igor Sikorsky Kyiv Polytechnic Institute», Ukraine, e-mail: lis.shv.vs@gmail.com,ORCID: http://orcid.org/0000-0002-5048-8601

Kulik Nadiya, Department of Scientific Analytical and Environmental Devices and Systems, National Technical University of Ukraine «Igor Sikorsky Kyiv Polytechnic Institute», Ukraine, e-mail: kulik.nadinka1996@gmail.com, ORCID: https://orcid.org/00000002-8686-2327

Havryliuk Vladyslav, Department of Scientific Analytical and Environmental Devices and Systems, National Technical University of Ukraine «Igor Sikorsky Kyiv Polytechnic Institute», Ukraine, e-mail: h.vladyslav87@gmail.com, ORCID: http://orcid.org/00000001-9046-7381
Vasiutynska K.,

Arsirii 0.,

Ivanov $\mathbf{0}$.

\section{DEVELOPMENT OF THE METHOD FOR ASSESSING THE ACTION ZONES OF HAZARDS IN AN EMERGENCY AT A CITY FILLING STATION USING GEOINFORMATION TECHNOLOGY}

Експериментально обгрунтовано технологічні властивості та структурно-механічні характеристики овочевих паст при різних гідромодулях обводнення порошків гідробіонтів та ламінарії. Досліджено вплив тривалості набрякання порошків гідробіонтів та ламінарії на властивості паст. Обгрунтовано вплив кониентраиї̈ гідратованих порошків ламінарії та гідробіонтів на структурно-механічні показники овочевих паст. Визначено рачіональний вміст гідратованих порошків з ламінарії та гідробіонтів.

Ключові слова: структурно-механічні характеристики, овочеві пасти, порошки гідробіонтів та ламінарії, йодовмісна сировина.

\section{Introduction}

The scientific and technological revolution (STR) during the XX-XXI centuries. caused a rapid development of the industry, the emergence of new industries, which has led to a redistribution of labor resources and the intensification of urbanization throughout the world. The general growth of the population led to the concentration of technogenic objects, including potentially dangerous ones, in metropolitan cities.

The process of forming security systems has become much more complicated through two important circumstances that simultaneously led to the expansion of the zones of the population's defeat:

1) increase in the number and density of population, to enhance its mobility, as well as the increase in the size of urban areas leads to a constant decrease in the distance from the potentially dangerous objects (PDO) in residential development zone;

2) toxic explosion fier hazardous are substances accumulated in the PDOs in such quantities that the consequences of accidents at these sites can be compared with the effects of severe natural disasters (earthquakes, tsunamis or hurricanes).

Maintaining the state of man's technogenic security on the priorities of a person's safe life, a healthy and safe environment is one of the most important tasks of the state. An important element of technological safety of the process is a procedure for assessing emergency risks in PDO, which is enshrined in the Law of Ukraine «On the major hazard», the Cabinet of Ministers of Ukraine «On the identification of and declaring the security of 